\title{
Particle movement in Sinhala and Japanese*
}

In Sinhala (Indo-Aryan, Sri Lanka), focus and question constructions are formed with particles that attach to the focused phrase or question word. Although on the surface these particles are usually clause-internal, this paper presents evidence that these particles move before interpretation to the periphery of the clause. The proposal is illustrated below in (1).

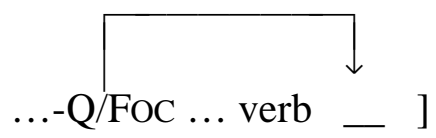

Along with strictly Sinhala-internal evidence, we will also consider evidence from Japanese, which (I will argue) shows the hypothesized particle movement in the surface syntax. That is, Sinhala and Japanese form a minimal pair with respect to whether the movement shown in (1) is "overt" (Japanese) or "covert" (Sinhala).

The syntactic structure of the focus and question constructions in Sinhala have been discussed in the previous literature, as has the potential similarity to Japanese. This paper builds on these works to varying degrees, primarily on Gair (1983), Gair \& Sumangala (1991), Sumangala (1992), Kishimoto (1991, 1992, 1997, 1998), and Whitman (1997), Yanagida (1995). ${ }^{1}$

Questions in Sinhala are generally formed with the use of the 'question particle' $d$. Compare the declarative sentence in (2), the yes-no question in (3), and the wh-object question in (4). The yes-no question differs from the declarative only in that the yes-no question has a clause-final $d$. As for the wh-question in (4), there are three things to notice. First, there is no obligatory movement of the $w h$-word; it appears in canonical object position. Second, the question word-which remains clause-internal-is followed by the question particle $d \partial$. Third, the verb in (4) appears in a special form, with a suffix that is glossed as '-E'.

Chitra ee potə kieuwa.

Sinhala

Chitra that book read

'Chitra read that book.'

Chitra ee potə kieuwa də?
Chitra that book read
'Did Chitra read that book?'

Chitra mokak də kieuwe?
Chitra what Q read-E
'What did Chitra read?'

\footnotetext{
* Many thanks to the patient consultants who helped me with the judgments reported here, particularly Dileep Chandralal, Ansela Gunawardana, Kumara Henadeerage, and Shigeru Miyagawa. Thanks also to Bob Frank, Martha McGinnis, and Norvin Richards for reading earlier drafts. Much of the material in this paper is condensed and refocused from Hagstrom (1998).

${ }^{1}$ It is worth indicating that Kishimoto (1998) has independently arrived at several of the same conclusions we reach here. This approach was also anticipated (in a slightly different form) by Yanagida (1995).
} 
Sinhala also has a focus construction which is formed in a way similar to the $w h$ questions above. In (5), the focus particle tamay follows the focused constituent, and the verb is marked with the '-E' morphology.,

$$
\begin{aligned}
& \text { Chitra ee potə tamay kieuwe. } \\
& \text { Chitra that book FOC read-E } \\
& \text { 'It was that book that Chitra read.' }
\end{aligned}
$$

Sinhala

\section{Cases where particle movement is overt}

Under certain circumstances, the focus and question particles can appear at the right edge of the clause instead of in their clause-internal position. We will begin the argument for particle movement by looking at these cases; these are situations in which the proposed movement has happened overtly.

The next few examples are intended to show two things. First, there are two positions in which the question particle $d z$ can appear, clause-finally and clauseinternally. Second, there is a correlation between the '-E' marking on the verb and the clause-internal position for $d \partial$. We will look at three cases in which $d \partial$ appears to have both positional options, internal or final. In each of these cases, we see that the '-E' morphology appears when (and only when) $d a$ is clause-internal.

When a question is embedded under certain verbs, including dannawa 'know', ${ }^{4} d a$ can appear either internally by the $w h$-word (6a) or peripherally (6b). ${ }^{5,6}$ Note that the "peripheral" position of an embedded clause (6b) is inside (to the left of) the complementizer kiyala; we will return to discuss this briefly in section 12 . The important point for now is that the embedded verb is marked with '-E' only in the first case, where do is clause-internal.

\footnotetext{
${ }^{2}$ An anonymous reviewer points out that the "focus particle" tamay is potentially too big to be a particle, and might perhaps be analyzed in some interesting compositional way. I have two comments to make about this. First, Gair (1970) indeed considered tamay to be composed of a focus particle tamaa and an "assertion marker" $-y$, which would be interesting to investigate further in its own right (among the intriguing things about $-y$ is the possible connection to the conjunctive particle $-y$, perhaps partly parallel with Japanese to). That said, tamay (or tamaa+-y) appears to share the same distribution as other focus particles, including $l u$ (reportative), ya (dubitative), and nee ("tag" question focus), so there is no clearly compelling reason to treat tamay differently (Kariyakarawana 1998:87-88). Of course, simply being two syllables long can only hint at internal structure, not really serve as an argument for it. For present purposes, therefore, I believe we are on safe enough ground considering tamay (or at least tamaa) to be monomorphemic.

${ }^{3}$ An anonymous reviewer inquired about whether this construction is properly considered a focus construction, as opposed to a topic construction. The existing work on this particle that I have found is quite clear that it in fact conveys a focused interpretation; that is, it marks non-presupposed information, often contrastive.

${ }^{4}$ Kishimoto (1998) also cites saka-karənəwa 'doubt', and parikšaa-kərənəwa 'look into' as verbs which have this property of allowing overt movement of $d \partial$ in their complement, and ahuwa 'asked' as verb which does not. Gair \& Sumangala (1991) characterize the clauses in which $d \partial$-movement can happen overtly as expressing 'general doubt,' although they do not elaborate further. An interesting possibility is that verbs which take an extensional complement (which would include know, doubt, but would not include ask) are those which allow the overt movement.

${ }^{5}$ Kauru 'who' is shortened to kau- when immediately followed by the question particle. Along with the previous literature on Sinhala question formation, I assume that this is a morphological fact with no syntactic consequences.

${ }^{6}$ If there is a difference in meaning between (6a) and (6b), it is very subtle. Kumara Henadeerage (p.c.) suggests that (6a) is more likely to involve a single, specific person than (6b). This requires more systematic investigation.
} 
b. Ranjit [ kauru aawa də kiyəla ] dannəwa. Ranjit who came $\mathbf{Q}$ that know 'Ranjit knows who came.'

Yes-no questions can also appear with a clause-internal $d$. Compare (7a) (repeating (3)) and (7b). In (7b), the question particle appears clause-internally, and simultaneously the verb is marked with the '-E' morphology. The question in (7b) is interpreted as having focus on the constituent to which $d a$ is attached.

a. Chitra ee potə kieuwa də?

Sinhala

Chitra that book read Q

b. Chitra də ee potə kieuwe?

Chitra $\mathbf{Q}$ that book read-E

'Did Chitra read that book?'

Finally, consider the questions in (8), which involve a scalar wh-word. ${ }^{7}$ With this class of wh-words (including kiidenek 'how many (animate)', kiiyak 'how many (inanimate)', koccəra 'how much'), the da marker can either appear clause-finally (8a), or clause-internally (8b). Where $d a$ is clause-internal, the '-E' morphology appears on the verb. The clause-internal $d a$ has a focusing effect in (8b) just as it did in (7b) above. ${ }^{8}$
a. kiidenek enəwa də?
'How many (animate) are coming?'
b. kiidenek də enne?
how.many $\mathbf{Q}$ come-E
'How many (animate) are coming?'

The focus particle has a flexibility in position similar to the question particle discussed above. The focus particle tamay can appear clause-internally (9a) (repeating (5)), marking the focused element directly, or it can appear clause-finally (9b). Notice two things. First, only when the focus particle is clause-internal does the '-E' morphology appear. Second, when the focus particle is clause-final, there are several available interpretations; the focused element is not unambiguously marked. This is expected under the view that the focus particle has moved to its surface position in (9b), since it might have moved from any of several positions; that is, (9b) is (structurally) ambiguous.

a. Chitra ee potə tamay kieuwe.

Sinhala Chitra that book FOC read-E 'It was that book that Chitra read.'

\footnotetext{
${ }^{7}$ Gair \& Sumangala (1991) refer to these $w h$-words as 'quantificational' but the term 'scalar' seems to capture the property these $w h$-words have more transparently.

${ }^{8}$ Ansela Gunawardana (p.c.) tells me that (8b) seems to presuppose that some people are coming. In contexts where $(8 \mathrm{~b})$ is appropriate, simply asking kiidenek? is also appropriate.
} 
b. Chitra ee potə kieuwa tamay.

Chitra that book read FOC

'It was that book that Chitra read.'

'It was read that book that Chitra did.'

'It was read that Chitra did with that book.'

In both questions and focus constructions, the '-E' morphology determines the "scope" of the question or focus. So, (10a) is an embedded question, with '-E' marking on the embedded verb, and (10b) is a matrix question, with '-E' marking on the matrix verb. Similarly, '-E' determines the scope for focus marking in (11).

a. Ranjit [ kau də aawe kiyəla] dannəwa.

Sinhala Ranjit who $\mathbf{Q}$ came-E that know 'Ranjit knows who came.'

b. Ranjit [ kau də aawa kiyəla ] danne? Ranjit who $\mathbf{Q}$ came that know-E 'Who does Ranjit know came?'

(11) a. Ranjit [ Chitra ee potə tamay kieuwa kiyəla] kiiwe. Ranjit Chitra that book FOC read that said-E 'It was that book that Ranjit said that Chitra read.'

b. Ranjit [ Chitra ee potə tamay kieuwe kiyəla] kiiwa. Ranjit Chitra that book FOC read-E that said 'Ranjit said that it was that book that Chitra read.'

The purpose of this section has been to highlight the connection between the particles (e.g., the question particle $d \partial$, the focus particle tamay) and the '-E' morphology on the verb. The connection is manifested both by the fact that either '-E' or the particle itself must be next to the verb in these constructions, and by the fact that (when the particle is clause-internal) '- $E$ ' determines the scope of the focus/question.

Notice also that, from a more theory-internal perspective, the connection between the particle and '-E' looks like a movement relation insofar as movement is assumed to be driven to "check" morphological features (Chomsky 1995). We can view the '-E' as an overt morphological reflex of an unchecked morphological feature that will drive movement of the particle. When this movement happens overtly, the feature corresponding to '- $E$ ' is checked (deleted) and so the morphology does not appear. In the other cases, the presence of '-E' indicates that the movement is "yet to happen" - that is, that it will happen in covert syntax. ${ }^{10}$ We will return to some discussion of the motivation behind this movement in section 9 .

\footnotetext{
${ }^{9}$ A note about the verbal morphology may be in order here when considering (10); where a verb (like dannawa) shows the ending -nawa it is in the present tense, the infinitive of which ends in -nna. The '-E' form of these verbs ends in -nne (apparently based on the infinitive form), hence the alternation between dannawa in (10a) and danne in (10b).

${ }^{10}$ For clarity, it is worth pointing out (as noted by an anonymous reviewer), that this morphological effect is some sense a reverse case of the cross-linguistically common marking of agreement on a head over which an argument has moved (e.g., French participles, Hungarian adpositions, Russian adjectives). In those cases, agreement morphology appears as a result of movement, whereas under the proposed view of the Sinhala '-E' marking, the '-E' marking disappears as a result of movement (the movement of $d$ o having checked/removed the feature which would have caused its appearance).
} 


\section{Island effects}

Gair (1983) observed that although wh-words are allowed inside complex noun phrase islands, the particle $d o$ cannot appear inside but must appear at the edge of the island. This is illustrated in (12-13) (examples from Kishimoto 1997). (12a) is ill-formed because $d \partial$ appears inside a complex noun phrase, while (12b) is fine, with $d \partial$ appearing just outside the complex noun phrase. The same point is made for adjunct islands by the examples in (13).

a. * oyaa [Chitra kaa-țe də dunnə potə] kieuwe? you Chitra who-DAT $\mathbf{Q}$ gave book read-E ('You read the book that Chitra gave to whom?')

Sinhala

b. oyaa [Chitra kaa-țe dunnə potə] də kieuwe? you Chitra who-DAT gave book $\mathbf{Q}$ read-E 'You read the book that Chitra gave to whom?'

a. * [Chitra monəwa də kanə koțə] Ranjit pudumə unee? Chitra what $\mathbf{Q}$ ate when Ranjit surprise became-E ('Ranjit was surprised when Chitra ate what?')

b. [Chitra monəwa kanə koțə] də Ranjit pudumə unee? Chitra what ate when $\mathbf{Q}$ Ranjit surprise became-E 'Ranjit was surprised when Chitra ate what?'

Assuming that adjuncts and complex noun phrases are islands for movement, this generalization supports the proposal that the question particle moves to the clause periphery covertly. In the (b) examples above, this movement is unimpeded, whereas in the (a) examples this movement would have to cross an island boundary.

For completeness, note that overt movement is also constrained by these islands. This is demonstrated in (14) for the "pseudocleft" construction, which is formed by moving the clefted constituent to a postverbal position. (14a) is well-formed, but (14b-c) are each ungrammatical because the extraction path crosses an island boundary (as observed by Gair 1983). In (15) we see the same effect for overt (leftward) scrambling. The point is that overt movement (like that attempted below) is constrained by the same islands as covert movement of $d a$ (hypothesized to account for the grammaticality patterns in (12-13) above).

$\begin{array}{llll}\text { a. lankaave ayə } & t_{\mathrm{i}} & \text { kanne } & \text { bat } \\ \text { Sri Lanka-GEN people } & \text { eat-E rice }\end{array}$

Sinhala 'It's rice that Sri Lankans eat.'

b. * oyaa [ Chitra $t_{\mathrm{i}}$ dunnə potə] kieuwe Ranjit-țə. you Chitra gave book read-E Ranjit-DAT ('It was to Ranjit that you read [the book that Chitra gave $t_{\mathrm{i}}$ ]')

c. * [Chitra $t_{\mathrm{i}}$ kanə koțə] Ranjit pudumə unee maalu ${ }_{\mathrm{i}}$. Chitra ate when Ranjit surprised became-E fish ('It was fish ${ }_{\mathrm{i}}$ that Ranjit was surprised [when Chitra ate $t_{\mathrm{i}}$ ')
a. Ranjit-ț $\partial_{\mathrm{i}}$, oyaa dannəwa [ Chitra $t_{\mathrm{i}}$ ee potə dunna kiyəla ] Ranjit-DAT, you know Chitra that book gave that 'To Ranjit, you know Chitra gave that book'


 b. * Ranjit-țə $\partial_{\mathrm{i}}$, oyaa [ $\begin{array}{lll}\text { Chitra } & t_{\mathrm{i}} & \text { dunnə potə] } \\ \text { Ranjit-DAT, you kieuwa } & \text { Chitra } & \text { gave book read }\end{array}$ 'To Ranjit, you read the book Chitra gave'

The generalization about islands holds for focus particles as well as for question particles; a focus particle separated from '- $E$ ' by an island boundary results in an illformed sentence (16a), but a focus particle which appears at the edge of an island is fine $(16 b)$.
a. * [Chitra maalu tamay kanə koțə] Ranjit pudumə unee. Chitra fish FOC ate when Ranjit surprise became-E ('It was fish that Ranjit was surprised when Chitra ate it.')
b. [Chitra maalu kanə koțə] tamay Ranjit pudumə unee. Chitra fish ate when FOC Ranjit surprise became-E 'It was when Chitra ate the fish that Ranjit was surprised.' * 'It was eat fish that Ranjit was surprised when Chitra did.' * 'It was fish that Ranjit was surprised when Chitra ate it.' * 'It was eat that Ranjit was surprised when Chitra did it to fish.' Sinhala

Notice that in (16b) the only available reading is the one in which the entire island is focused; it cannot be interpreted as having focus on a subconstituent of the island. Compare this with (9b) from before (where the overt movement of the focus particle rendered the utterance ambiguous because the particle could have moved from any of several positions). The fact that (16b) is unambiguous suggests that the particle does not head a chain whose tail is inside the island; rather, the focus particle surfaces in its lowest interpreted position. ${ }^{11}$

If we assume that focus particles and question particles behave in essentially the same way, we can further conclude that the question particle in (12-13) also appears in its base position.

\section{Question formation in Japanese}

At this point, we will turn to consider the properties of question formation in Japanese. We have seen in Sinhala that there is a connection between the question/focus particle and the clause periphery that has the properties of a movement relation. We will see that the particle movement we hypothesized as occurring covertly in Sinhala is overtly occurring in Japanese. ${ }^{12}$ Japanese provides a well-studied example which forms a nearminimal pair with Sinhala.

In Japanese, the question particle $k a$ (which, as we discuss in more detail below, corresponds to Sinhala $d \partial$ ) appears at the end of questions, both yes-no questions (18) and wh-questions (19) (to be compared with the declarative in (17)).

\footnotetext{
${ }^{11}$ Caveat: There is a slight oversimplification here, which we will not remedy in this paper. It turns out that evidence from Japanese indicates that the question particle analogous to Sinhala do originates inside such islands. The evidence is very subtle, and suggests the need for a non-feature-driven type of movement (dubbed "Migration" in Hagstrom 1998). Because nothing in this paper crucially hinges on this additional complication, I will not attempt to defend this further here. Instead, we will refer to this island-external position as the "base position" of the particle.

${ }^{12}$ Of course, we already saw (section 1) that question particles in Sinhala themselves sometimes move overtly. The difference between Sinhala and Japanese is that Japanese always moves the particle overtly.
} 
(17) John-ga hon-o kaimasita.

Japanese

John-NOM book-ACC bought.POLITE

'John bought a book.'

John-ga hon-o kaimasita ka?

John-NOM book-ACC bought.POLITE $\mathbf{Q}$

'Did John buy a book?'

John-ga nani-o kaimasita ka?

John-NOM what-ACC bought.POLITE $\mathbf{Q}$

'What did John buy?'

An obvious way to think of the structure of questions like (19), in light of the preceding discussion, is as involving a movement like that diagrammed in (20), where the question particle starts in a clause-internal position by the $w h$-word and moves to the clause-final position in overt syntax.

John-ga nani-o $t_{\mathrm{ka}}$ kaimasita ka

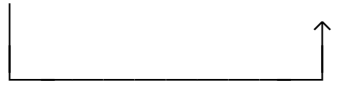

In support of the idea that Japanese $k a$ corresponds to Sinhala $d \partial$, we note a few facts. First, of course, this is the particle used in yes/no and wh-question formation, as we have already seen. However, there are other parallels as well. In both Sinhala and Japanese, indefinites can be formed by appending the question particle to a $w h$-word. Thus in (21), the same question particle — in each language - is used in combination with the $w h$-word meaning 'what' to form a word meaning 'something'. ${ }^{13}$

a. Chitra mokak də gatta.

Sinhala

Chitra what $\mathbf{Q}$ bought

'Chitra bought something.'

b. Taroo-ga nani-ka-o katta.

Taro-NOM what-Q-ACC bought

Japanese 'Taro bought something.'

Further, the question particle in both languages can be used to signal disjunction. In (22a), $d \partial$ is used to delimit alternatives in an alternative question in Sinhala, and in (22b), $k a$ is used to signal disjunction in a Japanese declarative. ${ }^{4}$

$$
\begin{aligned}
& \text { a. tee } \mathbf{d ə} \text { koopi də oonə? } \\
& \text { tea } \mathbf{Q} \text { coffee } \mathbf{Q} \text { necessary } \\
& \text { 'Do (you) want tea or coffee?' }
\end{aligned}
$$

Sinhala

\footnotetext{
${ }^{13}$ Another way to form an indefinite meaning 'something' in Sinhala is to append hari to a $w h$-word, as in mokak-hari 'what-HARI' = 'something'. The hari particle can also be used to signal disjunction except in alternative questions, as in Chitra-hari Siri-hari 'Chitra or Siri' (which would be Chitra-ka Siri(-ka) in Japanese). This suggests that the distinction between $d o$ and hari may be collapsed in the Japanese analog $k a$, although the details of the relation between $k a$ and hari have yet to be mapped out.

${ }^{14}$ Note that in Sinhala, $d a$ is only used to signal disjunction in alternative questions of this sort; for disjunction in other contexts, the particle hari can be used. Cf. footnote 13 above.
} 
b. John-ka Bill-(ka-)ga hon-o katta.

Japanese

'John or Bill bought books.'

Lastly, it is also worth pointing out that in an earlier stage in the history of Japanese, the question particle was positioned clause-internally (23a) — but islandexternally (23b) - just like in modern Sinhala. ${ }^{15}$

a. tare-ka mata hanatatibana-ni omoi-idemu. Premodern Japanese who-Q again flower.orange-DAT remember-M

'Who will again remember (me) at the time of the mandarin orange flower?'

(Shin Kokin Wakashū [1205]:3, Ogawa 1977:222)

b. [ika yoo naru kokorozasi aramu hito-ni]-ka awamu to obosu. how kind is love have person-DAT-Q wed that think-M '[What kind of love $]_{\mathrm{i}}$ do you think you would want to marry a person that has $\mathrm{t}_{\mathrm{i}}$ ?'

(Taketori Monogatari [c. 900], Ogawa 1977:216,

Whitman 1997:166)

\section{Island effects in Japanese}

If Japanese is really parallel to Sinhala in the way proposed above, then we predict that Japanese questions will also show island effects on the path of the particle movement. There is an inherent difficulty with testing this prediction, however, because the proposed movement is always overt. Since the particle always reaches its destination, and since it is possible (as we have seen in Sinhala) for the particle to start from a position outside an island, simply placing a $w h$-word inside an island does not guarantee that the question particle itself moved from within the island. What we need is some way to unambiguously determine the point from which the question particle moved.

Fortunately, Japanese has a particle which appears to give us the information we need. The emphatic particle ittai associates with $w h$-words to give a meaning approximating ' $w h$ in the world'. Pesetsky (1987), discussing the use of ittai, proposed that it forces the $w h$-word with which it is associated to take on a reading which is explicitly not restricted by context ("non-D-linked"). ${ }^{16}$ Here, we will use ittai as a diagnostic tool to locate the bottom of the movement chain.

(24) gives a simple example which both shows the use of ittai and shows that it is not constrained to appear in the matrix clause. As an aside, note that the question particle in Japanese is sometimes (in matrix questions) realized as no rather than as $k a,{ }^{17}$ a fact which we will for present purposes essentially ignore (treating instances of no as if they were $k a$ ), following the practice of most recent syntactic literature on Japanese questions.

\footnotetext{
${ }^{15}$ There were several particles in Premodern Japanese that participated in this construction (involving discontinuous particles and verbal morphology, a construction referred to traditionally as kakari-musubi), most of them with an emphasizing function, again like Sinhala.

${ }^{16}$ Note that even though we will adopt this characterization of the meaning of ittai, we will not adopt Pesetsky's (1987) assumption that non-D-linked wh-words must move. In the account being developed here, it is not the $w h$-words which must move, but the question particle.

${ }^{17}$ Which ending is chosen depends primarily on the politeness marking on the verb; $k a$ goes with verbs marked with polite morphology, no goes with unmarked verbs. No is usually thought to be short for no desu ka (no = nominalizer, desu = 'be'). Here (with nearly all of the syntactic literature on Japanese) we will make the probably harmless assumption that the variation between no and $k a$ is essentially contextual allomorphy, a fact about morpho-phonology and not about syntax or semantics.
} 
Now, notice that if ittai appears inside an island as in (25a), the question is illformed, whereas if ittai appears at the edge of an island as in (25b), the question is fine.

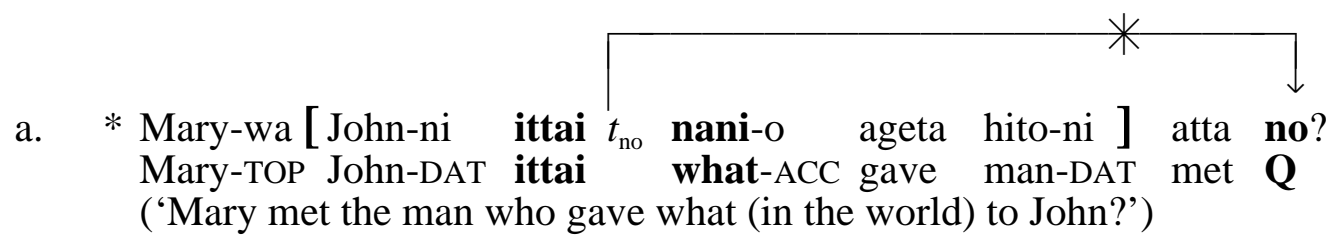
\begin{tabular}{lllll}
\cline { 2 - 3 } & & & \\
Mary-wa ittai & & \\
$t_{\text {no }}$ & John-ni nani-o ageta & hito-ni $]$ & atta & no? \\
John-DAT what-ACC gave & man-DAT & met & $\mathbf{Q}$
\end{tabular} 'Mary met the man who gave what (in the world) to John?'

This is very similar to the pattern we saw for Sinhala $d a$ in (12-13). If we suppose that ittai marks the base position of the question particle, we can account for the facts in the same way; (25a) is ill-formed because the question particle no must have had to move across an island boundary. ${ }^{18}$

In support of the view that ittai must be generated with the question particle (after which Q moves away leaving ittai behind), consider the following fact. It is possible in Japanese to ask a $w h$-question in which the question particle has been dropped, as in (26a). However, if ittai appears in the question, it is no longer possible to drop the question particle (26b). This shows that ittai depends on the presence of $k a$, which is consistent with the hypothesis that ittai localizes the base position of $k a$.

$$
\begin{aligned}
& \text { a. Hiro-ga nani-o tabeta? } \\
& \text { H-NOM what-ACC, ate } \\
& \text { 'What did Hiro eat?' } \\
& \text { b. ?? Hiro-ga ittai nani-o tabeta? } \\
& \text { H-NOM ittai what-ACC ate } \\
& \text { ('What in the world did Hiro eat?') }
\end{aligned}
$$

Thus, with the help of ittai, we have replicated in Japanese the island effects that motivated the particle-movement analysis of Sinhala questions. This suggests that the same movement occurs in both languages - overtly in Japanese, and (often) covertly in Sinhala.

\footnotetext{
${ }^{18}$ There is an additional complication introduced by the fact that ittai itself can be scrambled (like a numeral quantifier; cf. Miyagawa 1989). This means that the overt position of ittai doesn't necessarily mark the base position of the question particle, but instead sets an upper bound for it. Also, Q appears to move successive-cyclically, and ittai can be stranded in an intermediate position (either because ittai $+k a$ move together part of the way or because ittai is base-generated next to a derived position of $k a$ ). See Hagstrom (1998, ch. 2) for more discussion.
} 


\section{Intervention effects in Japanese}

There is a second argument for the particle-movement analysis of Japanese questions that can be made from "intervention effects." Hoji (1985) observes that, although word order in Japanese is generally free, questions like (27a) and (28a) are ill-formed where nani 'what' follows the indefinite dareka 'someone' or the disjunction John-ka Bill 'John or Bill'. However, the intended meanings can be perfectly well expressed by reversing the order of the $w h$-word and indefinite/disjunct, as in (27b) and (28b).
a. ?? dareka-ga nani-o nomimasita ka? someone-NOM what-ACC drank
Q ('What did someone drink?')
b. nani- $\mathrm{o}_{\mathrm{i}}$ dareka-ga $\mathrm{t}_{\mathrm{i}}$ nomimasita ka? what-ACC someone-NOM drank $\mathbf{Q}$ 'What did someone drink?'

Japanese John-or Bill-NOMwhat-ACC drank Q ('What did John or Bill drink?')
a. ?* [John-ka Bill]-ga nani-o nomimasita ka?
b. nani- $o_{\mathrm{i}} \quad\left[\right.$ John-ka Bill]-ga $\mathrm{t}_{\mathrm{i}}$ nomimasita ka? what-ACC John-or Bill-NOM drank Q 'What did John or Bill drink?'

Notice that the things (dareka, John-ka Bill) which cause this effect actually contain the question morpheme $k a{ }^{19}$ If, as has been proposed above, the question particle in questions like (28a) moves overtly to the clause periphery, it will have to cross this second instance of $k a$ contained within John-ka Bill. ${ }^{20}$ This is illustrated in (29a), and (29b) shows the well-formed case (where left-to-right order indicates hierarchy rather than linear surface order).

a.

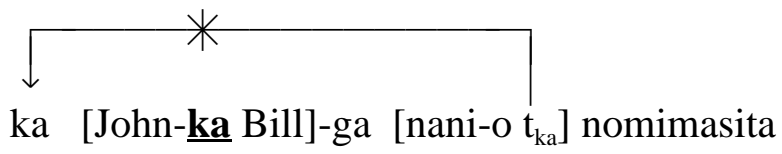

b. ka [nani-o $\left.\mathrm{t}_{\mathrm{ka}}\right]_{\mathrm{i}}\left[\mathrm{John}-\underline{\mathbf{k a}}\right.$ Bill]-ga $\mathrm{t}_{\mathrm{i}}$ nomimasita

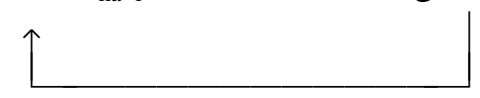

$=(28 \mathrm{~b})$

\footnotetext{
${ }^{19}$ As far as I know, the connection between the morphology and this type of intervention effect was first noticed by Shigeru Miyagawa.

${ }^{20}$ A word about what it means for the movement to "cross" an intervenor: I will assume that the sort of intervention effect being discussed in this section is stated in terms of c-command; that is, if an intervenor $I$ c-commands the base position of $\mathrm{Q}$, and the position to which $\mathrm{Q}$ is to be moved c-commands $I$, then the movement cannot take place ( $I$ having blocked it). This has certain implications for the structure of [John$k a$ Bill] in (29): if $k a$ 'or' c-commands $t_{k a}$, then $k a$ 'or' must be the head of a 'disjunction phrase', in the same spirit as Kayne's (1994) analysis of coordination. I will not pursue any further implications of this here.
} 
We suppose that movement is driven by a need to check a feature (in Sinhala, recall, this feature being morphologically realized as '-E'), and that the closest available element capable of checking the feature is the one which undergoes movement (basically following Chomsky 1995). This then gives us a ready explanation for why (28a) is illformed. We know of course that $k a$ is capable of checking the relevant feature, but if the "wrong" $k a$ (a $k a$ which is being used for something else in the interpretation, e.g. disjunction or formation of an indefinite) is moved to the clause periphery, the result will not be semantically interpretable. ${ }^{21}$

\section{Predicting the interaction between island effects and intervention effects}

Recall that we concluded earlier (see (16b)) that question/focus particles which appear at the edge of islands have not moved there from an island-internal position. ${ }^{22}$ Connecting this with the intervention facts discussed in the previous section provides us with an interesting and unusual prediction: If intervention effects are due to movement of the particle over an intervenor (such as dareka 'someone' in (27)), and if the particles do not start inside islands at whose periphery they appear, then there should not be any detectable intervention effects inside an island.

We can test this prediction in Japanese, and it indeed appears to be borne out. (30a) is ill-formed, just like (27a) from before, the reason being that the path of movement of the question particle must cross the ka of dareka. However, if the wh-word and quantifier are embedded inside an island, as in $(30 \mathrm{~b}-\mathrm{c})$, the order between them no longer affects their grammatical status. In other words, the intervention effect disappears inside of islands, just as predicted if the question particle in Japanese moves to the clause periphery from the edge of the island.
a. ?? dareka-ga nani-o katta no?
('What did someone buy?')
b. Mary-wa [ dareka-ga nani-o katta ato de] dekaketa no? Mary-TOP someone-NOM what-ACC bought after left $\mathbf{Q}$ 'Mary left before someone bought what?'
c. Mary-wa [ nani- $o_{i}$ dareka-ga $t_{i}$ katta ato de] dekaketa no? Mary-TOP what-ACC someone-NOM bought after left $\mathbf{Q}$ 'Mary left before someone bought what?'

The same pattern holds other intervenors, such as John-ka Bill 'John or Bill', shown in (31). Notice also that if the intervenor is outside of the island, as in (31d), the intervention effect returns, supporting the proposal that it is the path between the island and the clause periphery (i.e. the path of the proposed movement of the question particle) that matters for the intervention effect.

$$
\begin{aligned}
& \text { a. ?* [John-ka Bill]-ga nani-o katta no? } \\
& \text { John-or Bill-NOMwhat-ACC bought } \mathbf{Q} \\
& \text { ('What did John or Bill buy?') }
\end{aligned}
$$

\footnotetext{
${ }^{21}$ It is worth pointing out that in Japanese, words containing the morpheme mo (e.g., daremo 'everyone') also induce intervention effects, although perhaps slightly less dramatically. For this account to carry over to the intervention by daremo, it must be assumed that mo is relevantly like $k a$; that is, $k a$ and mo both have the feature which is being attracted when $k a$ is moved to the clause periphery in questions.

${ }^{22}$ But recall the caveat from footnote 11 .
} 

b. Mary-wa [ [John-ka Bill]-ga nani-o katta ato de] dekaketa no? Mary-TOP John-or Bill-NOMwhat-ACC bought after left Q 'Mary left after John or Bill bought what?'

c. Mary-wa [ nani-o $o_{i}$ [ John-ka Bill]-ga t $\mathrm{t}_{\mathrm{i}}$ katta ato de] dekaketa no? Mary-TOP what-ACC John-or Bill-NOM bought after left $\mathbf{Q}$ 'Mary left after John or Bill bought what?'

d. ?* [John-ka Bill]-wa [ Mary-ga nani-o katta ato de] dekaketa no? John-or Bill-TOP Mary-NOM what-ACC bought after left $\mathbf{Q}$ 'John or Bill left after Mary bought what?'

\section{State of the search for intervention effects in Sinhala}

The strongest case for a parallel treatment of Sinhala $d a$ and Japanese $k a$ would be to replicate the intervention effects seen above, in Sinhala. However, the data I have collected to date unfortunately remains murky. Starting with the clearest contrast I have found, we have (32), showing an apparent parallel to the Japanese intervention effect, where Sinhala $-t$, like Japanese - $m o$, creates a universal quantifier when affixed to a $w h$ word, and arguably blocks movement of $d a$ to the clause periphery, roughly analogous to (28) earlier.
a. ?? kauru-t mokak də kiiwe. who-T what $\mathbf{Q}$ said-E 'What did everyone say?'
b. mokak də kauru-t kiiwe. what $\mathbf{Q}$ who-T said-E
'What did everyone say?'

Sinhala

It also appears that embedding this in an island, for example an adverbial island in (33), improves the otherwise problematic ordering from (32a); in fact, there appears to be a preference in (33) for that order. This at least suggests that the fact in (32) is not based on a preference to put the $w h$-word first, and might well be an instance of an island "repairing" an intervention effect, as described in the previous section.

\footnotetext{
a. [ kauru-t mokak kiyənə koțə ] də Siri pudumə unee? who-T what did when $\mathbf{Q}$ Siri surprised was-E

'Siri was surprised when everyone did what?'

b. ? [ mokak kauru-t kiyənə koțə ] də Siri pudumə unee?

what who-T did when $\mathbf{Q}$ Siri surprised was-E

'Siri was surprised when everyone did what?'
}

While these initial facts appear promising, there seem to be additional complications which have so far kept me from making a stronger case for intervention effects in Sinhala beyond this. For example, examples with likely candidates for intervenors such as kauruhari 'someone' and kauda 'someone' have received mixed reviews from my consultants, suggesting to me that there are other factors that need to be identified and controlled for before the experiments will succeed in showing (or not showing) intervention effects in Sinhala. This is clearly a very interesting and critical area to investigate in future research. 


\section{Summary to this point}

Let us take a moment to recap the proposal and the evidence that has been discussed so far, before we turn to the remaining sections, which are more speculative.

The proposal is that in focus/question constructions in both Sinhala and Japanese, a particle moves from a clause-internal position (next to the focus or the $w h$-word) to a clause-final position, as illustrated in (34) (elaborating on (1)). ${ }^{23}$

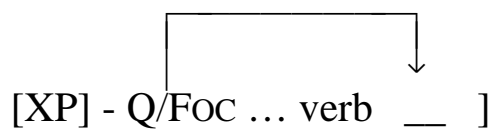

where XP is $w h$-word or focused phrase

In cases where the $w h$-word or focused phrase is contained within an island, the particle moves from a position just outside the island.

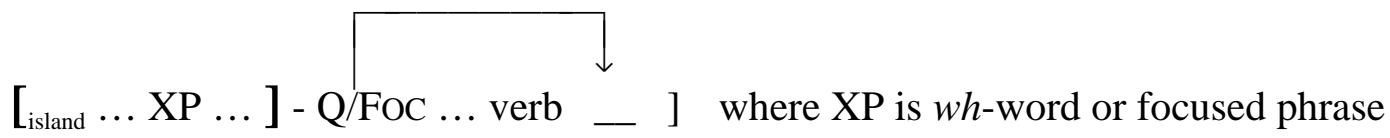

Evidence for this relation being a movement relation came from (a) the inability of the relation to cross island boundaries, (b) the fact that sometimes this movement is overt (under certain circumstances in Sinhala, and invariably in Japanese), and (c) the fact that the movement must be of the closest eligible element (that is, the path of movement cannot cross another instance of the moving morpheme-the "intervention effect").

In the next few sections, we will address a few of the questions that have been left open so far.

\section{Motivating Q-movement}

One question we should consider is why the Q particle needs to move. We hypothesized earlier that the $-e$ morphology which appears on the Sinhala verb is the morphological realization of an "unchecked feature" that drives the movement, but we have not taken any steps to try to identify that feature or the role of $\mathrm{Q}$ in the interpretation.

The first thing to notice is that $\mathrm{Q}$ itself does not confer interrogativity; we know this from the fact that $\mathrm{Q}$ is used to form indefinites from $w h$-words (mokak da 'something (S)' and nani-ka 'something (J)') in declarative sentences (recall (21)). Neither, for that matter, does the feature reflected by the $-e$ morphology in Sinhala, since $-e$ appears in declarative, focused sentences as well.

Without going into the full detail of a semantics for $w h$-questions and indefinites, we can still observe that they have existential quantification in common; something fell can be rendered as in (36a), whereas what fell? can (after Hamblin 1958 and much subsequent work on the semantics of questions) be rendered as in (36b) (whose value is a set of propositions of the form $x$ fell).

\footnotetext{
${ }^{23}$ As for the structure of yes-no questions, I have only speculative remarks to offer. In neutral yes-no questions (like (7a)), the answers allowed vary only at the level of the whole proposition; i.e. Chitra read that book or not(Chitra read that book). This would suggest that in such questions, the do particle originates at a fairly high position in the structure, for example attached to the IP (or whatever the appropriate structural position is which is the syntactic correlate of the semantic proposition). Presumably $d a$ still moves in a yes-no question, but just moves a very short distance to reach its surface position.
} 

a. $\quad \exists x . f e l l^{\prime}(x)$
b. $\lambda \mathrm{p} \exists \mathrm{x} . \mathrm{p}=\mathrm{fe} \mathrm{ll}^{\prime}(\mathrm{x})$
'something fell'
'what fell?'

Essentially, we can take the $w h$-word to be restricting the range of values that $x$ can take on in the answer (e.g., kauru 'who (S)' restricts $x$ to being drawn from the set of humans), and take the Q particle to be contributing the existential quantification. A primary difference between (36a) and (36b) is in the location of the existential quantifier; in (36a), the quantifier is inside the proposition, whereas in (36b), it is outside. This correlates with what we see syntactically as well, e.g., in (37). In (37b), there is a (covert) movement of $d \partial$ to the clause periphery, high in the structure. If IP is the syntactic correlate of the semantic proposition, then $d a$ has plausibly been moved out of the domain of the proposition (by the point of interpretation). ${ }^{24}$
a. Chitra mokak də kieuwa.
Chitra what $\mathbf{Q}$ read
'Chitra read something.'
b. Chitra mokak də kieuwe?
Chitra what $\mathbf{Q}$ read-E
'What did Chitra read?'

This leaves us with the conclusion that the $-e$ morphology reflects a feature whose task it is to pull the quantifier out of the proposition. We can suppose it has the same role in focus constructions as well, like (5), repeated below. The meaning of (5) can be roughly stated as in (38), where B stands for that book and the values of $x$ are drawn from the (contextually relevant) alternatives to that book (Jackendoff 1972, Rooth 1992). To paraphrase (38), $\mathrm{C}$ read $\mathrm{B}$, and for all $x$ such that $x$ is an alternative thing that $\mathrm{C}$ could have read, C didn't read $x$ (except where $x$ is $\mathrm{B}$ ).

Chitra ee potə tamay kieuwe.

Sinhala

Chitra that book FOC read-E

'It was that book that Chitra read.'

a. $\quad \operatorname{read}^{\prime}(\mathrm{C}, \mathrm{B})$ is true; and

b. of the alternatives $\left(\lambda \mathrm{p} \exists \mathrm{x} \cdot \mathrm{p}=\operatorname{read}^{\prime}(\mathrm{C}, \mathrm{x})\right)$, none is true except $\operatorname{read}^{\prime}(\mathrm{C}, \mathrm{B})$.

The main thing to notice is that the set of propositions in (38b) has the same form as the one in (36b); an existential quantifier has been moved out of the proposition. To put it another way, the alternative set for (5) is the same set of propositions as for the question in $(37 b)$.

We still must suppose that there is something (without morphological realization) that makes a sentence interrogative (for example, an interrogative complementizer) and

\footnotetext{
${ }^{24}$ I have chosen to be as neutral as possible about what syntactic projection is the correlate of the semantic proposition simply because here it does not affect the point. By referring to "IP" I do not wish to suggest that this proposal is incompatible with any kind of "split-INFL" (Pollock 1989) or "fine structure of CP" (Rizzi 1997) syntactic analysis. The assumption is that there is some projection which can be identified with a complete semantic proposition, and it is to this projection I refer. To clarify one other point brought up by an anonymous reviewer, I do not intend to be referring to the kind of semantic completeness that is used by Chomsky (1999) to motivate phase boundaries; while there is a sense in which $v \mathrm{P}$ can be considered to have complete prepositional content, it still lacks the semantics associated with tense and could not be evaluated as true or false. The projection I refer to is presumably either one of the upper phrases in "IP" or one of the lower phrases in "CP". This discussion continues in section 12.
} 
which bears this unchecked feature that attracts quantifiers like Q. This part of the structure is presumed also to be responsible for the remaining semantic part of (36b) (the part abstracting over propositions). Likewise, in sentences with focus, a comparable abstract head must be present to bear the feature realized as $-e$ and to contribute the remainder of the semantics in $(38 b){ }^{25}$

\section{Multiple questions}

The hypothesis that the question particle moves (in $w h$-questions) from next to the $w h$ word to the clause periphery immediately leads us to wonder about the structure of questions with more than one $w h$-word. More specifically, in a multiple question, is there one particle per $w h$-word, or one particle per interrogative clause? And if there is but one particle per clause, by which $w h$-word does it begin?

The evidence bearing on this issue is unfortunately quite murky. A first thing to notice is that multiple questions in Japanese, like (39), have only a single clause-final question marker. This suggests that there is not one $k a$ per $w h$-word, but rather one $k a$ per interrogative clause.

$$
\begin{aligned}
& \text { dare-ga nani-o kaimasita ka? } \\
& \text { who-NOM what-ACC bought.POLITE Q } \\
& \text { 'Who bought what?' }
\end{aligned}
$$

Japanese

If there is a single question particle per clause, the next issue to consider is: where does that particle start? In questions with a single $w h$-word, the particle starts by the $w h$ word (modulo islands), as we learned from the various Sinhala examples discussed earlier.

To address this issue, we start by considering (40). ${ }^{26}$ In (40a), the question particle $d a$ follows the second $w h$-word, and the result is a grammatical question, while in (40b), $d a$ follows the first $w h$-word and produces an ill-formed question.

$$
\begin{aligned}
& \text { a. } \quad[\text { kauru mokak də kieuwe kiyəla] dannəwa də? } \\
& \text { who what } \mathbf{Q} \text { read-E that know } \\
& \text { 'Do (you) know who read what?' } \\
& \text { b. * [kau də mokak kieuwe kiyəla] dannəwa də? } \\
& \text { who } \mathbf{Q} \text { what read-E that know } \\
& \text { ('Do (you) know who read what?') }
\end{aligned}
$$

Sinhala

What (40) tells us is that, if we were right to conclude from (39) that there is one question particle per clause, this question particle must be attached to the lower $w h$-word. However, there is a potential problem, posed by the acceptability of (41). In (41), both $w h$-words are marked with an overt question particle. So, our problem is that (39) and (41) seem to point us toward exactly opposite conclusions.
kau də monəwa
də kieuwe?
who $\mathbf{Q}$ what $\mathbf{Q}$ read-E
'Who read what?'

\footnotetext{
${ }^{25}$ The semantics of $w h$-questions and indefinites are developed in much more detail in Hagstrom (1998).

${ }^{26} \mathrm{We}$ are using an embedded question in (40) because in general multiple wh-questions in Sinhala sound better when embedded than they do as simple matrix questions. The matrix clause ('Do (you) know...?') is irrelevant to the point being made.
} 
Sumangala (1992) argues for the one-particle-per-interrogative-clause view by providing a possible alternative analysis for (41). Crediting Jim Gair for the suggestion, Sumangala proposes that (41) is actually elliptical for (42). In support of this position, Sumangala indicates that although (40a) allows a pair-list answer, (41) does not, nor does $(42) .^{27}$

kau də kiewe monəwa də kiewe? who $\mathbf{Q}$ read-E what $\mathbf{Q}$ read-E

Sinhala 'Who read, what did s/he read?'

The idea here is that the existence of the pair-list reading in (40a) diagnoses a true multiple question, whereas the lack of such a reading in (41) indicates that its source is probably something like (42). ${ }^{28}$

Though perhaps not conclusive, the available evidence seems to indicate that in multiple questions, a single question particle (per interrogative clause) moves from the lower of two $w h$-words to the clause periphery; that is, that (40) shows us the basic structure of multiple questions. ${ }^{29}$

\section{The size of the moving element}

Kishimoto (1992), analyzing mostly the same Sinhala facts reviewed in this paper, concludes not that $d a$ moves to clause periphery itself, but rather that it marks the constituent which as a whole moves in covert syntax (adapting an influential proposal put forth by Nishigauchi 1990). Thus, in cases like those reviewed in section 2, where a whword is inside a movement island and $d a$ is attached outside, Kishimoto's proposal is that the entire island (marked by $d \partial$ ) moves (covertly) to the appropriate position for interpretation (i.e., SpecCP). Most of the Sinhala data we have seen so far do not distinguish between the two proposals (particle movement and movement of the whole island). ${ }^{30}$

Notice, however, that having argued for a correlation between Sinhala $d \partial$ and Japanese $k a$, we have also gained an argument for the particle-movement view (against the "LF pied piping" view that would move the whole island), since in Japanese we can see the movement overtly and it is only the particle that moves. Moreover, we had cases

\footnotetext{
${ }^{27}$ Actually, the example Sumangala discusses is (i), which differs from (40a) in that the question marker has already moved to the periphery of the embedded clause (something which is allowed here because dannəwa 'know' allows overt movement of the question particle; recall (6)).

(i) mokak kauru kiewa də dannəwa də? what who read Q know Q 'Do you know who read what?'

${ }^{28}$ The structure of (42) itself is not clear either. Nevertheless, it is clearly not a simplex clause. A reviewer points out that this raises the question of whether (22a) (the alternative question) might similarly be elliptical. Having no analysis of alternative questions, I have nothing additional to offer on that point. ${ }^{29}$ In Hagstrom (1998), I present a series of arguments from the availability of pair-list readings with Japanese multiple questions that converges on this conclusion as well. The semantics of pair-list questions developed there in fact relies on the question particle starting from a position below one of the $w h$-words.

${ }^{30}$ Kishimoto (1992), using Sinhala data translated from parallel Japanese and Korean examples discussed by Choe (1987), does provide an argument that the whole island moves based on Weak Crossover effects. However, as pointed out by von Stechow (1996), the facts presented there do not argue for movement of the whole island in the general case, only in the cases in which a pronoun needs to be bound by something which does not c-command it on the surface (a criticism which itself is based on a parallel criticism made by Rooth 1985 against Weak Crossover evidence for movement-based accounts of focus interpretation).
} 
even from within Sinhala (e.g., embedded under dannawa 'know') that show essentially the same thing, that only the particle moves. ${ }^{31}$

\section{The destination of movement}

Recall sentences like (43) (repeating (6)). These are cases in which a question is embedded under dannawa 'know' and in which the particle movement happens overtly (checking off the feature that would otherwise result in the '-E' morphology). In this situation, $d \partial$ appears to left of, and presumably hierarchically below, the complementizer kiyola.

$$
\begin{aligned}
& \text { b. Ranjit [ kauru aawa də kiyəla ] dannəwa. } \\
& \text { Ranjit who came } \mathbf{Q} \text { that know } \\
& \text { 'Ranjit knows who came.' }
\end{aligned}
$$

The fact that this movement checks a feature which can be realized on the verb as '-E' morphology suggests that $d a$ in (43) is attached to the verb (or something the verb is attached to), rather than, say, head-adjoined to kiyola.

On this point, we find that when $d a$ follows an $a$-marked verb, they cannot be split by an adverb like iiye 'yesterday'. (44a) shows that iiye can follow an $e$-marked verb (with $d a$ clause-internal), while (44b-d) shows that once $d a$ has moved, iiye can only be preverbal. This suggests that the verb and $d \partial$ form a tight unit. ${ }^{32}$

$$
\begin{aligned}
& \text { a. [kau də aawe iiye kiyəla ] Ranjit dannəwa. } \\
& \text { who } \mathbf{Q} \text { came-E yesterday that Ranjit know } \\
& \text { 'Ranjit knows who came.' } \\
& \begin{array}{lllll}
\text { b. } \quad[\text { kauru iiye } & \text { aawa də kiyəla }] \text { Ranjit dannəwa. } \\
\text { who yesterday came } & \mathbf{Q} \text { that Ranjit know }
\end{array} \\
& \text { 'Ranjit knows who came.' } \\
& \begin{array}{c}
\text { c. ?* }[\text { kauru aawa də iiye } \\
\text { who came } \mathbf{Q} \text { yesterday that }] \text { Ranjit dannəwa. } \\
\text { 'Ranjit knows who came.' }
\end{array} \\
& \text { d. * [kauru aawa iiye də kiyəla ] Ranjit dannəwa. } \\
& \text { who came yesterday } Q \text { that Ranjit know }
\end{aligned}
$$

In response to the fact that $d \partial$ appears to move lower than kiyala, Kishimoto (1998) proposes a recursive CP structure for Sinhala, with the higher CP being responsible for clause typing (headed by kiyzla) and the lower $\mathrm{CP}$ being the destination for operator movement. This is the solution I would at least tentatively adopt as well. Translated into the terminology of Rizzi's (1997) "split CP" structure, kiyala represents the head of "ForceP" (though note that it does not distinguish interrogative from noninterrogative clauses, which might cast suspicion on that label), while $d o$ moves to a lower head like "FocusP".

\footnotetext{
${ }^{31}$ As mentioned in footnote 1, Kishimoto (1998) takes a view much closer to that proposed here, although he does not explicitly argue against his previous proposal. He proposes that $d \partial$ is a clitic which moves to fix the scope of $w h$-phrases.

${ }^{32}$ It may also indicate that the verb moves higher in the structure when it is not $e$-marked.
} 
I should perhaps close this section with some speculation in connection with the intentional and consistent "vagueness" herein about the precise syntactic positions involved in these movements. It seems likely that, as just mentioned, the Q particle moves to a position low in the split CP, probably to adjoin to a Focus ${ }^{\circ}$ head, but the only evidence we really have is that it comes after the verb and before kiyzla. ${ }^{33}$ Due to the fact that Sinhala is a head-final language, it is difficult to pinpoint where head movement has occurred, since such movement is generally string-vacuous. My speculative assumptions are that the verb moves up in standard fashion to a position quite close to the Focus ${ }^{\circ}$ head, close enough that the feature on the Focus ${ }^{\circ}$ head responsible for the '-E' morphology can be spelled out as a suffix on the verb when present, assuming some form of morphological Merger roughly as in Distributed Morphology (Halle \& Marantz 1993). Of course, future research might be able to confirm or deny the predictions this makes, but this has not been our primary focus here.

Another point which has not been made explicit is where exactly the Q particle originates (and, in Sinhala, generally surfaces) syntactically, other than to position it clause-internally "next to a $w h$-word." Again, I have little concrete evidence that bears on this question, but my assumption is that it is in either an upper projection in a DP, or is a postposition-like element taking the $w h$-word (or, in some cases, an entire island containing a $w h$-word) as its complement. The evidence we have seen seems to point this way, but a full investigation of this part of the structure will need to grapple with questions of how this affects syntactic selection as well as details of how it is incorporated into the structure when at the edge of an island. While none of these potential issues appear to be insurmountable problems, there are too many alternative possibilities open to really sensibly commit to one over another until more pertinent evidence is explored.

\section{Closing remark}

While there are clearly many issues left open (most notably with respect to the points brought up in the previous few sections), the particle-movement perspective on Sinhala focus and question constructions not only holds promise in explaining the patterns within the Sinhala data, but also leads us to ask questions we would not otherwise have thought to ask in languages like Japanese where the same structures are detectable but in some ways more obscured. The structures of focus and questions in Sinhala can shed considerable light on the structure of such constructions in language generally, and hopefully we will see many further developments in the evidence and argumentation in research to come.

\section{References}

Choe, Jae W. (1987). LF movement and pied-piping. Linguistic Inquiry 18(2):348-353. Chomsky, Noam (1995). The minimalist program. Cambridge, MA: MIT Press.

\footnotetext{
${ }^{33}$ I should point out that assuming Q moves to Focus ${ }^{\circ}$ in this way seems to require assuming that the Head Movement Constraint (Travis 1984) does not apply to this movement. However, apart from this, it looks much like head movement; given that Sinhala and Japanese are head-final (SOV) languages, the canonical position for heads is on the right edge of the structure, and this appears to be where these particles go. If we were to assume that these particles move into a specifier position (which would make moot any issues concerning the HMC), we would either have to allow for rightward specifiers or derive the structures from underlying SVO structures à la Kayne (1994) (cf. Whitman 1998 for discussion along these lines). Taking the particle movement to be pure feature movement is also a possibility (and one which would make "Migration" operation mentioned in fn. 11 look more like feature percolation). At this point, I have no real evidence to decide between these alternatives.
} 
Chomsky, Noam (1999). Derivation by Phase. MIT Occasional Papers in Linguistics 18. Cambridge, MA: MIT Working Papers in Linguistics.

Gair, James (1983). Non-configurationality, movement, and Sinhala focus. Paper presented to the Linguistics Association of Great Britain. Reprinted in Gair (1998).

Gair, James (1998). Studies in south Asian linguistics: Sinhala and other South Asian languages. New York: Oxford University Press.

Gair, James, and Lelwala Sumangala (1991). What to focus in Sinhala. In the proceedings of the Eastern States Conference on Linguistics (ESCOL) '91.

Hagstrom, Paul (1998). Decomposing questions. Ph.D. dissertation, Massachusetts Institute of Technology. Distributed by MIT Working Papers in Linguistics.

Halle, Morris, and Alec Marantz (1993). Distributed morphology and the pieces of inflection. In K. Hale and S. J. Keyser (eds.), The view from Building 20. Cambridge, MA: MIT Press.

Hamblin, C.L. (1958). Questions. Australasian Journal of Philosophy 36(3):159-168.

Hoji, Hajime (1985). Logical form constraints and configurational structures in Japanese. Ph.D. dissertation, University of Washington.

Jackendoff, Ray (1972). Semantic interpretation in generative grammar. Cambridge, MA: MIT Press.

Kariyakarawana, S.M. (1998). The syntax of focus and wh-questions in Sinhala. Colombo: Karunaratne \& Sons Ltd. (Revised, published version of Sumangala 1992).

Kayne, Richard (1994). The antisymmetry of syntax. Cambridge, MA: MIT Press.

Kishimoto, Hideki (1991). On the nature of quantificational expressions and their logical form. Ph.D. dissertation, Kobe University.

Kishimoto, Hideki (1992). LF pied-piping: Evidence from Sinhala. Gengo Kenkyu 102:46-87.

Kishimoto, Hideki (1997). Wh-in-situ and null operator movement in Sinhala questions. Ms., Hyogo University of Teacher Education. Draft dated 10/21/97.

Kishimoto, Hideki (1998). Wh-in-situ and movement in Sinhala questions. Ms., Hyogo University of Teacher Education. Draft dated 12/7/1998.

Miyagawa, Shigeru (1989). Structure and case marking in Japanese, Syntax and Semantics 22. New York: Academic Press.

Nishigauchi, Taisuke (1990). Quantification in the theory of grammar. Dordrecht: Kluwer.

Ogawa, Kunihiko (1976). Japanese interrogatives: A synchronic and diachronic analysis. Ph.D. dissertation, University of California, San Diego.

Pesetsky, David (1987). Wh-in-situ: Movement and unselective binding. In Eric J. Reuland and Alice G.B. ter Meulen (eds.), The representation of (in)definiteness, Cambridge, MA: MIT Press.

Pollock, Jean-Yves (1989). Verb movement, universal grammar, and the structure of IP. Linguistic Inquiry 20:365-424.

Rizzi, Luigi (1997). The fine structure of the left periphery. In Haegeman, L. (ed.), Elements of Grammar: Handbook in Generative Syntax. Dordrecht: Kluwer.

Rooth, Mats (1985). Association with focus. Ph.D. dissertation, University of Massachusetts, Amherst.

Rooth, Mats (1992). A theory of focus interpretation. Natural Language Semantics $1: 75-116$.

von Stechow, Arnim (1996). Against LF pied piping. Natural Language Semantics 4(1):57-110.

Sumangala, Lelwala (1992). Long distance dependencies in Sinhala: The syntax of focus and WH questions. Ph.D. dissertation, Cornell University.

Travis, Lisa (1984). Parameters and the effects of word order variation. Ph.D. dissertation, Massachusetts Institute of Technology. 
Whitman, John (1997). Kakarimusubi from a comparative perspective. In Ho-min Sohn and John Haig (eds.), Japanese/Korean Linguistics 6. Stanford, CA: CSLI.

Whitman, John (1998). Kayne 1994: P. 143, fn. 3. Ms., Cornell University.

Yanagida, Yuko (1995). Focus projection and wh-head movement. Ph.D. dissertation, Cornell University. 